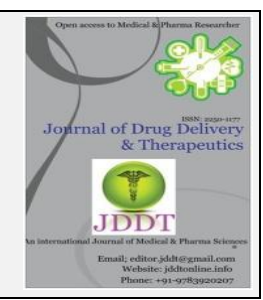

Open $\odot$ Access

Research Article

\title{
Synthesis, characterization and antimitotic activity of N-benzyl piperidin 4- one oxime
}

\author{
K. Sundaresan*, M. Thangavel and K. Tharini \\ Dept of Chemistry, Govt Arts College, Trichy-22, Tamil Nadu, India
}

\begin{abstract}
The aim of this study was to synthesize, characterization and antimitotic activity of N-Benzyl piperidin 4-one oxime derivative. The synthesized compound was characterized by IR, ${ }^{13} \mathrm{C}$ and ${ }^{1} \mathrm{H}$ NMR spectral studies. The synthesized compound was subjected to antimitotic studies of alliumcepa root meristamatic cells. The mitotic activity was observed in 3 different concentrations of N-Benzyl piperidin 4-one oxime. Our findings support the reported therapeutic use of this compound as a antimitotic or anticancer agent in the Indian system of medicine.
\end{abstract}

Keywords: N-Benzyl piperidin 4-one oxime, meristamatic cells, mitotic index.

Article Info: Received 03 Dec 2018; Review Completed 09 Jan 2019; Accepted 11 Jan 2019; Available online 15 Jan 2019

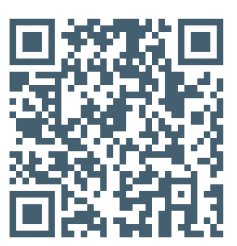

Cite this article as:

Sundaresan K, Thangavel M, Tharini K, Synthesis, characterization and antimitotic activity of N-benzyl piperidin 4-one oxime, Journal of Drug Delivery and Therapeutics. 2019; 9(1):233-236 DOI: http://dx.doi.org/10.22270/jddt.v9i1.2228

*Address for Correspondence:

K. Sundaresan, Dept of Chemistry, Govt Arts College, Trichy-22, Tamil Nadu, India

\section{INTRODUCTION}

Aromatic hetero cyclic chemistry is an enormous and complex subject of great industrial and academic significance. A number of molecules of life are derived from aromatic heterocycles and many pharmaceutical and agrochemical compounds are based on aromatic Heterocycles. A cyclic aromatic compound containing all Catoms in ring formation is referred to as a carboxylic compound. If at least one atom other than carbon form a part of ring system then it is designated as a heterocyclic compound. Pharmaceutical that can cure or prevent diseases for ex: anti-fertility agent for population control, pesticides, plant and animal hormones to increase food production and nutritional quality, polymers, fabrics, dyes, cosmetics detergents and photographic. Their derivatives having N-C linkage have been used in the fields of medicinal and pharmaceutical chemistry and reported to exhibit a variety of biological activities ${ }^{1-3}$.

\section{MATERIALS AND METHODS}

All the chemicals (solvents and reagents) were purchased from foreign companies (Hi-media and Sigma/Aldrich) and were used as such with no further purification and distillation. Local chemical has not been used in the research work. The purity of these chemicals was 98-99.9\%. The hydroxyl amine hydrochloride (Hi-media sigma/Aldrich) was used as received. The other reagents used were sodium acetate and sodium hydroxide (Merck). Analytical grade solvents like ethanol, methanol, ethyl acetate, chloroform $\left(\mathrm{CHCl}_{3}\right)$ and $\mathrm{N}$-hexane were used as such without further ISSN: 2250-1177 distillation. The synthesized compounds were scaled for yield and purified by recrystallization with suitable solvent system.

IR spectra were recorded in AVATAR-330 FT-IR spectrophotometer (Thermo Nicolet) and only noteworthy absorption levels (reciprocal centimeters) are listed. ${ }^{1} \mathrm{H}$ NMR spectra were recorded on BRUKER AMX $300 \mathrm{MHz}$ and 300 MHz NMR recorded on a BRUKER AMX $300 \mathrm{MHz}$ NMR spectrometer operating at $100 \mathrm{MHz}$. For recording ${ }^{1} \mathrm{H}$ NMR spectrum of compound solution were prepared by dissolving about $10 \mathrm{mg}$ of the compound in $0.5 \mathrm{ml}$ of $\mathrm{CDCl}_{3}$ was used as solvent while for ${ }^{13} \mathrm{C}$ NMR spectra, about $50 \mathrm{mg}$ of the compound was dissolved in the same volume of the respective solvents. TMS (Tetra methyl silane) was used as a internal standard.

\section{Preparation of N-benzyl piperidin-4-one oxime}

To the boiling solution of $\mathrm{N}$-benzyl piperidin-4-one $(0.01$ mol) in methanol $(45 \mathrm{ml})$ and few sodium acetate, hydroxylamine hydrochloride $(0.01 \mathrm{~mol})$ and the methanol solution were added by stirring. The reaction was refluxed for 4hours on a water bath. After cooling, the solid productwas filtered and recrystallized from methanol to get the corresponding oxime. 


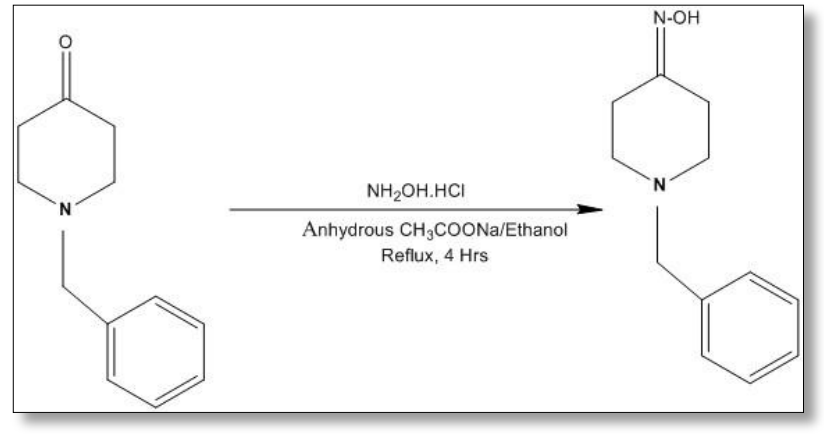

\section{Determination of antimitotic activity}

Evaluation of antimitotic activity using Allium cepa roots

Antimitotic activity study was conducted as per the methods reported by previous workers with modifications 4, 5 (Grant, 1982; Fiskesjo, 1988; Shweta et al.2014).

\section{Allium cepa Bulbs:}

Approximately equal size bulbs $(40 \pm 10 \mathrm{~g})$ of the onions (Allium cepa L.) were obtained from the local vegetable market at Thanjavur, Tamil Nadu, India. Any onions that were dry, moldy or have started shooting green leaves were discarded.

\section{Growing Allium cepa Meristems:}

The outer scales were removed from the healthy onion bulbs leaving the root primordia intact. These bulbs were grown in dark for $48 \mathrm{~h}$ over $100 \mathrm{ml}$ of tap water at ambient temperature until the roots have grown to approximately 3 $\mathrm{cm}$. The water was changed daily during this period. The viable bulbs were then selected and used for subsequent studies.

\section{Exposure to Text Samples}

The bulbs with root tips grown up to $2-3 \mathrm{~cm}$ were removed from the water and placed on a layer of tissue paper to remove excess of water. The bulbs were divided into four groups. The first group served as control (tap water). Second group: Allium cepa roots were dipped in the S1 $(10 \mu \mathrm{g} / \mathrm{mL})$. Third group: Allium cepa roots were dipped in the S2 $(20$ $\mu \mathrm{g} / \mathrm{mL}$ ).Fourth group: Allium cepa roots were dipped in the $\mathrm{S} 3(30 \mu \mathrm{g} / \mathrm{mL})$. Fifth group: Allium cepa roots were dipped in the Methotrexate $(0.10 \mathrm{mg} / \mathrm{mL})$ was used as a standard control. All the groups were incubated at $25 \pm 2^{\circ} \mathrm{C}$ for $96 \mathrm{~h}$ away from direct sunlight. The test samples were changed daily with fresh ones. The length of roots number and the mitotic index were recorded after $96 \mathrm{~h}$. The \% of root growth inhibition was calculated by

$$
\% \text { of root growth inhibition }=\frac{\text { Control-Test }}{\text { Control }} \times 100
$$

The effective concentration for 50\% root length inhibition (EC50 value) was determined by plotting the treatment concentrations against mean root lengths as percentage of water control group.

\section{Microscopic Studies and Determination of Mitotic Index:}

After $96 \mathrm{~h}$, the roots tips were fixed with fixing solution of acetic acid and alcohol (1:3). Squash preparations were made by staining the treated roots with acetocarmine stain 6 (Badria et al., 2001). For each root tip, the numbers of mitotic cells and total meristematic cells were counted manually in 5-8 fields of view high resolution (100x) bright field light microscopy.

The mitotic index was calculated by

$$
\text { Mitotic Index }=\frac{\text { Number of dividing cells }}{\text { Total numbers of cells }} \times 100
$$

\section{RESULTS AND DISCUSSION}

Table 1: Analytical and spectral data of N-benzyl piperidin-4-one oxime

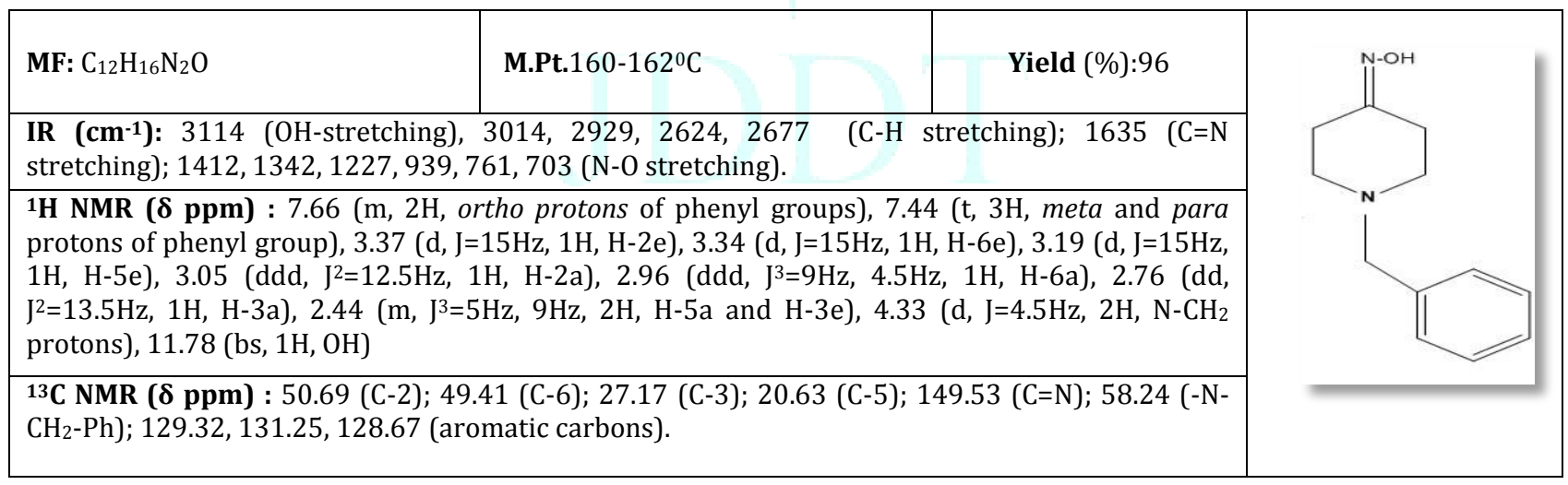

\section{Antimitotic Study ${ }^{7-9}$}

\section{Antimitotic activity of compound using Allium cepa root meristamatic cells}

The antimitotic activity was screened using Allium cepa root meristamatic cells which have been used extensively in screening of drugs with antimitotic activity. The inhibitory effect of methanolic extract of compound was evaluated on the growth and mitotic activity of A. Cepa root meristems and the effect was compared with standard anticancer drug Methotrexate. A progressive increase in average mean root length $(8.10 \mathrm{~mm})$, average mean root numbers (7) and mitotic index (88.88\%) observed in control group after 96 hrs of experimental period. The methanolic extract of compound and Methotrexate produced root decay and decreased the root length and root number significantly at $96 \mathrm{~h}$ as compared to control. The average mean root length at 10,20 , and $30 \mathrm{mg} / \mathrm{mL}$ of compound was $6.10 \mathrm{~mm}, 5.10 \mathrm{~mm}$ and $3.20 \mathrm{~mm}$ at $96 \mathrm{hr}$ respectively while standard shows $2.60 \mathrm{~mm}$. The average mean root numbers at 10,20 and $30 \mathrm{mg} / \mathrm{mL}$ of compound was 5,5 and 4 at $96 \mathrm{hr}$ respectively while standard shows 2 numbers. The mitotic index at 10 , 20 , and $30 \mathrm{mg} / \mathrm{mL}$ of compound was $81.25,69.09$, and $57.69 \%$ at $96 \mathrm{hr}$ respectively while standard shows $45.09 \%$. The highest dose as $30 \mathrm{mg} / \mathrm{mL}$ of compound has significant activity in root length, number and mitotic index and near to the standard. 
Effect of Compound on root length, root number and mitotic index of Allium cepa roots

Table 2: Effect of Compound on root length, root number and mitotic index of Allium cepa roots

\begin{tabular}{|l|c|c|c|c|}
\hline \multirow{2}{*}{ Groups } & \multicolumn{2}{|c|}{ Mean root length (mm) } & Mean root Numbers (s) & $\begin{array}{c}\text { Mitotic index } \\
\text { (\%) }\end{array}$ \\
\cline { 2 - 5 } & $\begin{array}{c}\text { Average root } \\
\text { growth }\end{array}$ & $\begin{array}{c}\text { \% of root growth } \\
\text { inhibition }\end{array}$ & Average root numbers & 88.88 \\
\hline Group I (Water control) & 8.10 & --------- & 7 & 81.25 \\
\hline $10 \mu \mathrm{g} / \mathrm{ml}(\mathrm{S} 1)$ & 6.10 & 24.69 & 5 & 69.09 \\
\hline $20 \mu \mathrm{g} / \mathrm{ml}(\mathrm{S} 2)$ & 5.10 & 37.03 & 5 & 57.69 \\
\hline $30 \mu \mathrm{g} / \mathrm{ml}(\mathrm{S} 3)$ & 3.20 & 60.49 & 4 & 45.09 \\
\hline Std. Methotrexate $(0.1 \mathrm{mg} / \mathrm{ml})$ & 2.60 & 67.90 & 2 & \\
\hline
\end{tabular}

Morphometric study on Allium cepa roots with different concentrations of compound

The water control shows normal growth with greater root length and numbers. Treatment with different concentrations $(10,20$ and $30 \mathrm{mg} / \mathrm{mL})$ of compound extract shows decreased the growth gradually in dose dependent manner. The highest dose $(30 \mathrm{mg} / \mathrm{mL})$ and standard has significantly reduced the root length and number compared to other doses and near to the standard.

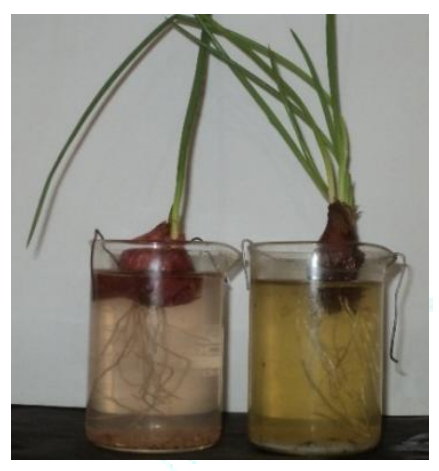

Water control

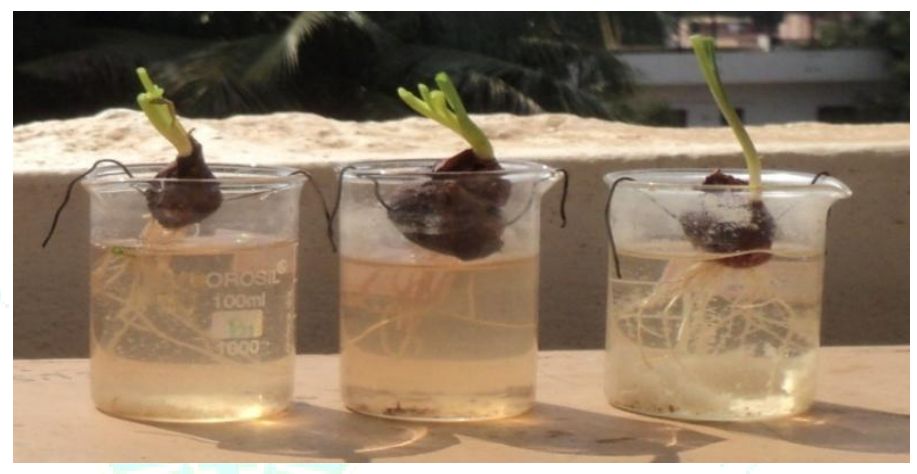

$10 \mu \mathrm{g} / \mathrm{ml}(\mathrm{S} 1)$

$20 \mu \mathrm{g} / \mathrm{ml}(\mathrm{S} 2)$

$30 \mu \mathrm{g} / \mathrm{ml}(\mathrm{S} 3)$

Allium cepa roots with different concentrations of compound

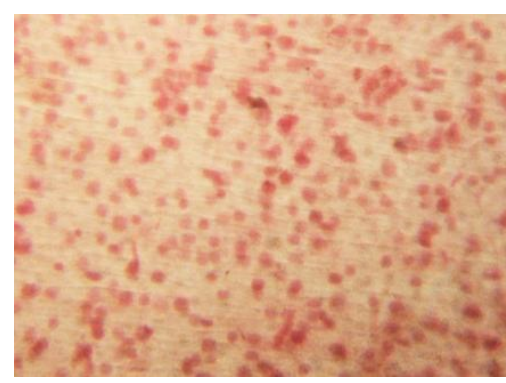

Water

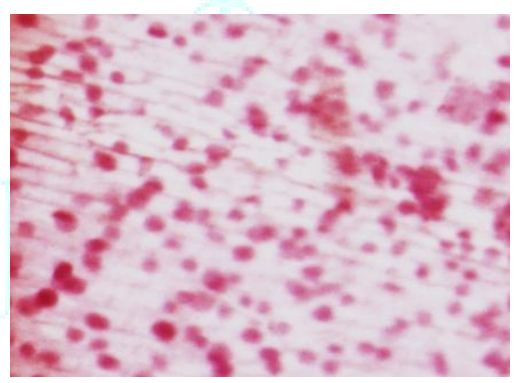

$10 \mu \mathrm{g} / \mathrm{ml}(\mathrm{S1})$

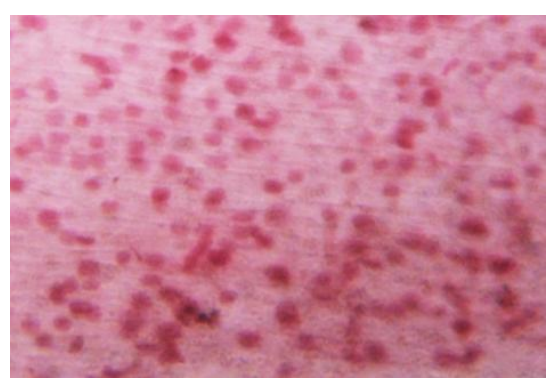

$20 \mu \mathrm{g} / \mathrm{ml}(\mathrm{S} 2)$

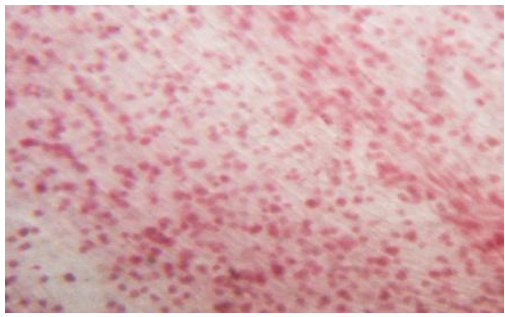

$30 \mu \mathrm{g} / \mathrm{ml}(\mathrm{S} 3)$

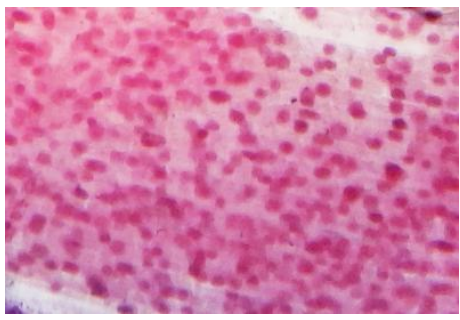

Std. Methotrexate $(0.1 \mathrm{mg} / \mathrm{ml})$

Photomicrograph of Compound on mitotic index of Allium cepa root

The antimitotic activity was screened using Allium cepa root meristamatic cells which have been used extensively in screening of drugs with anticancer compounds. Cytotoxicity at all concentrations test extract were evidenced by evaluating macroscopic parameters, i.e., reduction in root number and root length both of which were indicative of root growth inhibition. In the present study mitotic index of different concentrations of extract clearly indicates the efficiency in the inhibition of growth of cancer cells either by ISSN: 2250-1177 affecting microtubules or encouraging microtubule formation, and thus stopping the microtubules from being broken down. This makes the cells become so clogged with microtubules that they cannot continue to grow and divide. The rate of tumor growth is dependent upon a balance between the rates of proliferation and apoptosis. 


\section{CONCLUSION}

The structures of the synthesized compound are established on the basis of their analytical and spectral data (IR, ${ }^{1} \mathrm{H}$ NMR, ${ }^{13} \mathrm{C}$ NMR). The synthesized compound was subjected to preliminary antimitotic studies by Allium cepa root MERISTAMATIC CELLS. The result from the study showed that the N-benzyl piperidin-4-one oxime had excellent antimitotic activity that was comparable to the activity of methotrexate. Maximum numbers of non dividing cells were observed. As a result of this cells arrest in mitosis and eventually die by apoptosis.

\section{REFERENCES}

1. Hasan M.U.; Arab, M.; Pandiarajan K.; Sekar R.; Marko D. Magn. Reson. Chem. 1985, 23, 292.

2. Pandiarajan K.; Sabapathy Mohan R.T.; Krishnakumar, R. Indian J. Chem. 1987, 26B, 624.
3. Pandiarajan K.; Sekar R.; Anantharaman, R.; Ramalingam, V. Indian J. Chem.1991, 30B, 490.

4. Fiskesjo G., The Allium test-an alternative in environmental studies, the relative toxicity of metal. Mutation Res. 1988, 197:243-260.

5. Shweta SS, Tapadiya GG, Lamale JJ, Khadabadi SS. Phytochemical screening and antioxidant, antimitotic and antiproliferative activities of Trichodesma indicum shoot. Ancient Sci Life 2014:34:113

6. Badria F.A.R., Houssein W.E., Zaghloul M.G., Halim A.F., Antimitotic activity of gossypol and gossypolone. Pharmaceutical Biol., 2001, 39:120 - 126

7. Fisun K and Rasgele P. G. "Genotoxic effects of Raxil on root tips and anthers of Allium cepa L." Caryologia. 2009, 62:1, 1-9.

8. Helsel Z.R. Pesticide use in world agriculture. In: Stout, B. A, Energy in World agriculture, Elsevier, New York. 1987. 2, 179195.

9. Abhang R.Y, Jogiekar PP, Kulkarni P H. Preliminary on the effect of T.cordifolia.on mitosis, Ancient sci 1991; 1:27. 